\title{
Spleen Tyrosine Kinase Signaling Promotes Myeloid Cell Recruitment and Kidney Damage after Renal Ischemia/Reperfusion Injury
}

\author{
Jessica Ryan, ${ }^{* \dagger}$ John Kanellis, ${ }^{* \dagger}$ Kate Blease, ${ }^{\ddagger}$ Frank Y. Ma, ${ }^{* \dagger}$ and David J. Nikolic-Paterson ${ }^{* \dagger}$
}

From the Departments of Nephrology* and Medicine, ${ }^{\dagger}$ Monash Medical Centre, Clayton, Victoria, Australia; and the Department of Pharmacology, ${ }^{\ddagger}$ Celgene, San Diego, California

Accepted for publication April 6, 2016.

Address correspondence to David J. Nikolic-Paterson, Ph.D., Department of Nephrology, Monash Medical Centre, 246 Clayton Rd., Clayton, Victoria 3168 , Australia. E-mail: david. nikolic-paterson@monash.edu.

\begin{abstract}
Ischemia/reperfusion (I/R) injury is an important cause of acute and chronic renal failure. Neutrophils and macrophages, by integrin-based recruitment, play a key role in renal I/R injury. Integrin-based activation of spleen tyrosine kinase (Syk) contributes to myeloid cell adhesion to activated endothelial cells in vitro; however, whether Syk is required for myeloid cell recruitment and tubular damage in I/R injury is unknown. Therefore, we investigated the function of Syk in mouse I/R injury using two different approaches. $\mathrm{C} 57 \mathrm{Bl} / 6 \mathrm{~J}$ mice underwent bilateral warm ischemia and were sacrificed after 30 minutes or 24 hours of reperfusion. Mice were treated with the Syk inhibitor CC0417, or vehicle, beginning 1 hour before surgery. Syk was expressed by infiltrating neutrophils, macrophages, and platelets in vehicle-treated I/R injury which exhibited severe renal failure and tubular damage at 24 hours. CC0417 treatment markedly reduced neutrophil, macrophage, and platelet accumulation with improved renal function and reduced tubular damage. Next, we compared mice with conditional Syk gene deletion in myeloid cells $\left(S y k^{M y}\right.$ ) versus $S y k^{f / f}$ littermate controls in a 24-hour study. Syk ${ }^{M y}$ mice also showed a marked reduction in neutrophil and macrophage infiltration with significant protection from I/R-induced acute renal failure and tubular damage. These studies define a pathologic role for myeloid Syk signaling in renal I/R injury and identify Syk as a potential therapeutic target in this condition. (Am J Pathol 2016, 186: 2032-2042; http://dx.doi.org/10.1016/j.ajpath.2016.04.007)
\end{abstract}

Renal ischemia/reperfusion (I/R) injury is a major clinical problem with significant morbidity and mortality. It is the leading cause of acute renal failure after renal transplantation, shock, sepsis, and renal artery stenosis. Renal I/R injury in transplantation is associated with delayed graft function and is one of the major risk factors for acute renal transplant rejection. In addition, acute I/R injury also greatly increases the risk of development of chronic rejection and other chronic renal diseases. ${ }^{1-3}$ Current therapies for renal $\mathrm{I} / \mathrm{R}$ injury are still only supportive. Therefore, it is important to gain knowledge of the underlying mechanisms and to try to identify potential therapeutic targets.

The pathogenesis of renal I/R injury is complex and involves both direct damage to tubular epithelial cells through hypoxia/ re-oxygenation and ATP depletion, as well as indirect tubular damage through the recruitment and activation of neutrophils, monocyte/macrophages, and platelets. $^{4-6}$ Although the participation of leukocytes and platelets in I/R injury is well established, we have only a limited understanding of the signaling events involved in this key pathologic process.

Spleen tyrosine kinase (Syk) is a nonreceptor tyrosine kinase strongly up-regulated on $\mathrm{I} / \mathrm{R}$ injury in the murine kidney. ${ }^{7}$ It is expressed by most leukocyte populations, except mature $\mathrm{T}$ cells, as well as by some nonhematopoietic linage

Supported by the National Health and Medical Research Council (NHMRC) of Australia grant 1002079 (D.J.N.-P., F.Y.M., J.K.) and a NHMRC Senior Research Fellowship 1058175 (D.J.N.-P.).

F.Y.M. and D.J.N.-P. contributed equally to this work.

Disclosures: K.B. is an employee of and holds stock options in Celgene. D.J.N.-P. has previously received research funding from Celgene for studies unrelated to the present manuscript. CC0417 was supplied by Celgene.

Portions of this work were presented in abstract form at the 49th Annual Meeting of the Australian and New Zealand Society of Nephrology, September 9-11, 2013, Brisbane, QLD, Australia. 
cells. ${ }^{8,9}$ Syk is best known for its role downstream of immune receptors to trigger a series of signaling pathways leading to proliferation, survival, differentiation, migration, and production of reactive oxygen species and cytokines. ${ }^{9}$ Syk has been shown to promote antibody-associated glomerulonephritis and rheumatoid arthritis injury by facilitating activation of neutrophils, macrophages, and platelets. ${ }^{10-16}$ The protective effects of nonselective kinase inhibitors in models of $\mathrm{I} / \mathrm{R}$ injury in retina, brain, and intestine suggest that Syk may be involved in this response. ${ }^{17-20}$ However, a role for Syk in I/R injury remains to be established.

Our aim was to determine whether Syk signaling plays a pathologic role in renal I/R injury using both genetic and pharmaceutical approaches.

\section{Materials and Methods}

\section{Antibodies}

The following antibodies were used in this study: rat antimouse CD68 and fluorescein isothiocyanate-conjugated F4/80 (Serotec, Oxford, UK) both of which recognize macrophages; unconjugated and allophycocyanin-conjugated rat anti-mouse GR1 that recognize neutrophils (BioLegend, San Diego, CA); rat anti-mouse CD41 that recognizes activated platelets (Serotec); rabbit anti-fibrinogen $\gamma$ (Santa Cruz Biotechnology, Santa Cruz, CA), rabbit anti-Syk (Cell Signaling, Danvers, MA), and mouse antitubulin (Sigma-Aldrich, Castle Hill, NSW, Australia). Secondary antibodies for immunofluorescence staining included fluorescein isothiocyanate-conjugated sheep anti-rabbit $\mathrm{IgG}$, fluorescein isothiocyanate-conjugated rabbit anti-rat IgG (Serotec), and allophycocyanin-conjugated goat anti-rabbit IgG (Invitrogen, Eugene, OR). The biotinylated secondary antibody was goat anti-rabbit IgG (Invitrogen) which was detected with an avidin-biotin complex kit (Vector Laboratories, Burlingame, CA). Other secondary detection systems included horseradish peroxidase-conjugated rabbit anti-rat $\mathrm{IgG}$ and rat peroxidase-conjugated anti-peroxidase complexes (Dako, Glostrup, Denmark).

\section{Syk Inhibitor CC0482417}

CC0482417 (CC0417) was manufactured by Celgene (San Diego, CA). CC0417 inhibits Syk enzyme activity with a concentration that inhibits $50 \%\left(\mathrm{IC}_{50}\right)$ of $3.1 \mathrm{nmol} / \mathrm{L}$. In a panel of 71 enzymes, the closest enzymes inhibited were Janus kinase $2\left(\mathrm{IC}_{50}, 15.9 \mathrm{nmol} / \mathrm{L}\right)$, Janus kinase $1\left(\mathrm{IC}_{50}\right.$, $16.5 \mathrm{nmol} / \mathrm{L})$, and Janus kinase $3\left(\mathrm{IC}_{50}, 34.7 \mathrm{nmol} / \mathrm{L}\right)$. CC0417 has no activity against $\zeta$-associated protein $70 .^{21}$ CC0417 was prepared in 20\% hydroxylpropyl- $\beta$-cyclodextrin vehicle (Sigma-Aldrich) and administered by twice daily gavage at $30 \mathrm{mg} / \mathrm{kg}$ as previously described. ${ }^{21}$

\section{Mouse Model of Renal I/R Injury}

Male C57Bl/6J mice were obtained from Monash Animal Research Platform (Clayton, VIC, Australia). Syk ${ }^{f / f}$ mice were a kind gift from Professor Alexander Tarakhovsky (The Rockefeller University, New York, NY) ${ }^{22}$ and were backcrossed onto the C57BL/6J background for eight generations. Syk fff mice were then crossed with LysM $M^{\text {Cre }}$ mice $(\mathrm{C} 57 \mathrm{BL} / 6 \mathrm{~J})$ to produce $S y k^{M y}$ mice that have $S y k$ deletion in neutrophils and macrophages as previously described. ${ }^{23}$ All mice used were male and aged between 9 to 12 weeks.

Mice were anesthetized with ketamine/xylazine and then placed on a heating blanket with a rectal temperature probe to maintain body temperature at $37^{\circ} \mathrm{C}$. After abdominal incision, both renal pedicles were clamped using nontraumatic vascular clamps. The abdomen was closed with temporary sutures to reduce fluid and heat loss. After ischemia, clamps were removed, reperfusion of the kidneys was visually confirmed, and then animals were fully sutured. Mice were given intraperitoneal normal saline postoperatively. Pilot studies investigating periods of 15 to 22 minutes of warm ischemia were performed and identified that ischemic periods of 17 and 19 minutes induced reliable and severe acute kidney injury at 24 hours without causing loss of animals.

In the first experiment, groups of C57B1/6J mice $(n=8)$ underwent I/R surgery (19 minutes of ischemia) and were treated twice daily with $30 \mathrm{mg} / \mathrm{kg}$ Syk inhibitor CC0417 or vehicle, given by oral gavage, beginning 1 hour before surgery. Animals were euthanized 24 hours after reperfusion. To investigate the early events after reperfusion, groups of mice $(n=8)$ treated with CC0417 or vehicle were sacrificed 30 minutes after reperfusion. Sham-operated mice were used as controls.

In the second experiment, $S y k^{M y}(n=8)$ or $S y k^{f / f t}$ $(n=8)$ mice underwent $\mathrm{I} / \mathrm{R}$ surgery (17 minutes of ischemia) as described earlier in this section and sacrificed after 24 hours. Sham-operated animals were used as controls. All animal experiments were approved by Monash Medical Center Animal Ethics Committee.

\section{Histologic Examination}

Periodic acid-Schiff staining was performed on $2-\mu \mathrm{m}$ sections of formalin-fixed tissue. The outer medulla of the right kidney from each animal was examined under high power $(\times 400)$. Tubular damage was defined as tubular swelling (gross enlargement and partial detachment from the tubular basement membrane), loss of the brush border, or nuclear loss and expressed as the percentage of tubules exhibiting damage. All analysis was performed on blinded slides (J.R. and F.Y.M.).

\section{Immunohistochemistry}

Immunoperoxidase staining for fibrinogen was performed on formalin-fixed sections with antigen retrieval (citrate buffer, $\mathrm{pH}$ 6.0) using an avidin-biotin complex method. Immunostaining for Syk, neutrophils, macrophages, and 
platelets was performed on paraformaldehyde-fixed cryostat sections using a peroxidase-conjugated anti-peroxidase method. Two color immunofluorescence staining for Syk, macrophages, neutrophils, and platelets was performed on paraformaldehyde-fixed cryostat sections using a Nikon C1 confocal microscope (Nikon, Melville, NY).

The number of interstitial $\mathrm{CD}^{+} 8^{+}$macrophages and GR$1^{+}$neutrophils were counted in at least 20 high-power fields $(\times 400)$ in the outer medulla in each animal and expressed as cells per $\mathrm{mm}^{2}$. Immunostaining for fibrinogen and $\mathrm{CD} 41^{+}$platelets was assessed as positively stained clumps per $\mathrm{mm}^{2}$ under high-power $(\times 400)$ in the outer medulla or as area stained using ImageJ software version 1.41 (NIH, Bethesda, MD). ${ }^{24}$

\section{Real-Time RT-PCR}

Real-time PCR was performed as described previously. ${ }^{25-27}$ Mouse kidney cross-section samples were snap-frozen in liquid nitrogen and stored at $-80^{\circ} \mathrm{C}$ until RNA was extracted using a RiboPure RNA isolation kit (Ambion, Austin, TX). cDNA was prepared from total RNA by reverse transcription using random hexamer primers (Invitrogen). Real-time PCR was performed on a StepOne machine (Applied Biosystems, Scoresby, VIC, Australia) with thermal cycling conditions of $37^{\circ} \mathrm{C}$ for 10 minutes, $95^{\circ} \mathrm{C}$ for 5 minutes, followed by 50 cycles of $95^{\circ} \mathrm{C}$ for 15 seconds, $60^{\circ} \mathrm{C}$ for 20 seconds, and $68^{\circ} \mathrm{C}$ for 20 seconds. The primer pairs and FAM-labeled minor groove binder probes were
A SYK sham

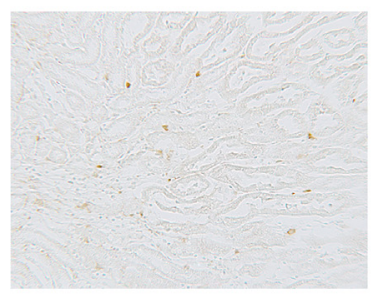

B
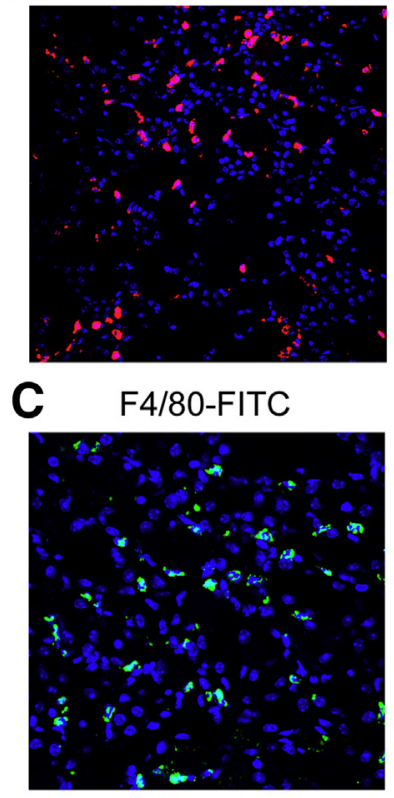

D CD41-FITC

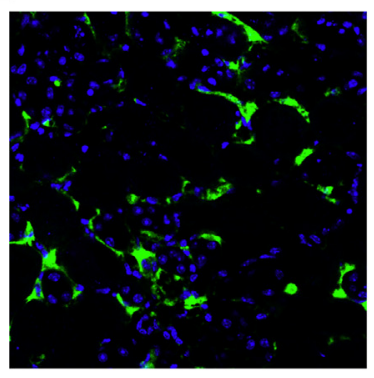

SYK Veh IR

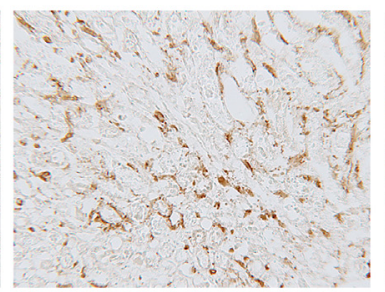

SYK-FITC

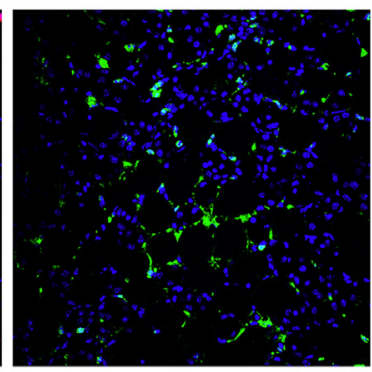

SYK-APC

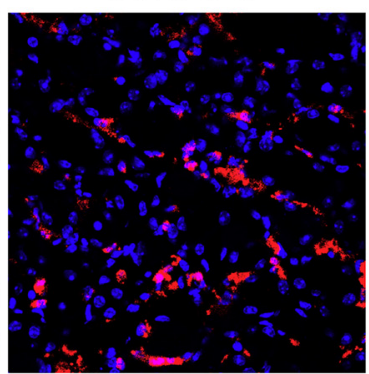

SYK-APC

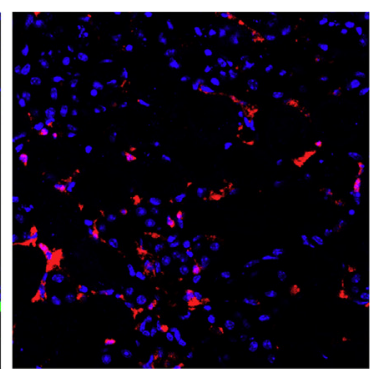

SYK CC0417 IR
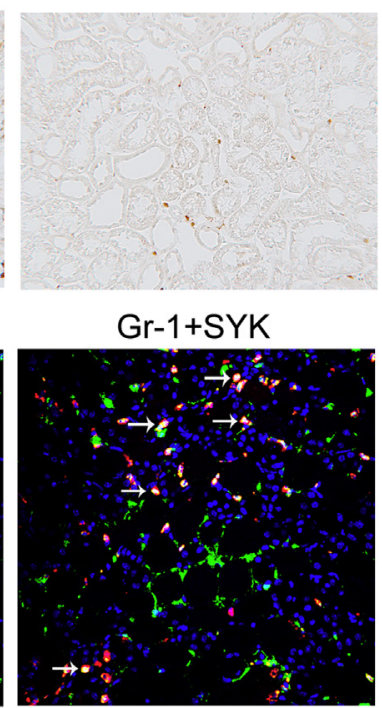

F $4 / 80+S Y K$

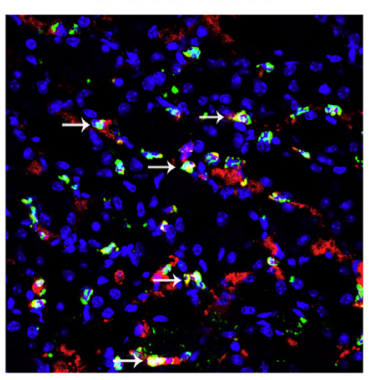

CD41+SYK

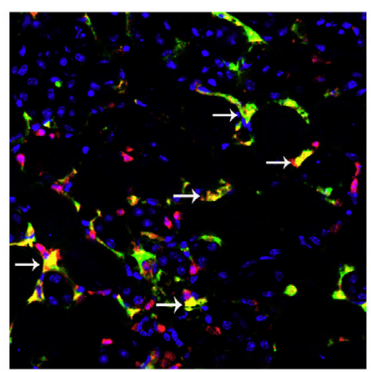

Figure 1 Expression of Syk in mouse I/R kidney. A: Immunoperoxidase staining for Syk in sham-operated and in vehicle- and CC0417-treated animals at 24 hours after reperfusion. B: Two-color confocal images showing colocalization of $\mathrm{Gr}-1^{+}$ neutrophils (green) with $\mathrm{Syk}^{+}$cells (red) in I/R kidney with double-stained cells indicated as yellow (arrows) in the merged image. C: Two-color confocal images showing colocalization of $\mathrm{F} 4 /$ $80^{+}$macrophages (green) with $\mathrm{Syk}^{+}$cells (red) in I/R kidney with double-stained cells indicated in yellow (arrows). D: Two-color confocal images showing colocalization of $\mathrm{CD} 41^{+}$platelets (green) with Syk (red) in I/R kidney with double-stained cells shown in yellow (arrows). B-D: Sections are counterstained with DAPI (blue). Original magnification, $\times 250$ (A-D). APC, allophycocyanin; FITC, fluorescein isothiocyanate; I/R, ischemia/reperfusion; SYK, spleen tyrosine kinase; Veh, vehicle. 


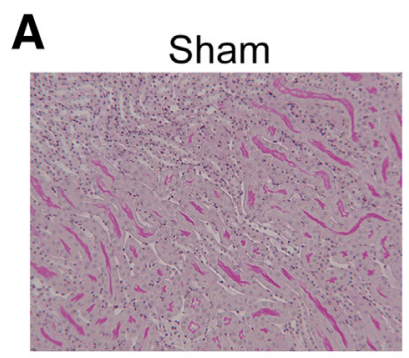

B Sham
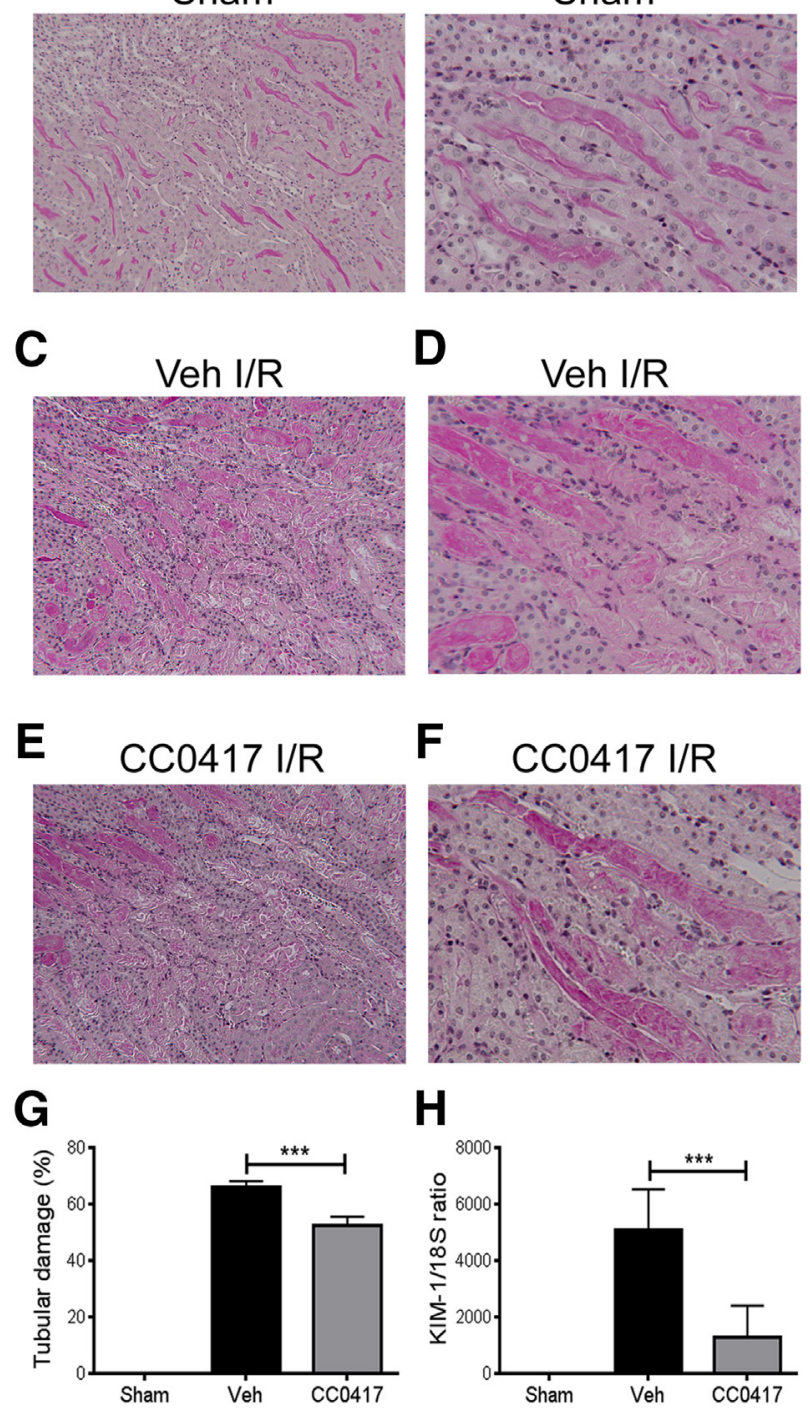

Figure 2 Effect of CCO417 on histologic damage at 24 hours after renal I/R injury. A-F: Periodic acid-Schiff-stained sections of sham-operated (A and B), Veh-treated I/R (C and D), and CC0417-treated (E and F) I/R. G: Quantification of the percentage of injured tubules in the outer medulla. $\mathbf{H :}$ Real-time RT-PCR analysis of KIM-1 mRNA levels. Data are expressed as means \pm SD. $n=8(\mathbf{G}$ and $\mathbf{H})$. ${ }^{* * *} P<0.001$ (one-way analysis of variance with Bonferroni's multiple-comparison test). Original magnification: $\times 250$ $(\mathbf{A}, \mathbf{C}$, and $\mathbf{E}) ; \times 400(\mathbf{B}, \mathbf{D}$, and F). I/R, ischemia/reperfusion; KIM-1, kidney injury molecule 1 ; Veh, vehicle.

obtained from Applied Biosystems or designed as previously described. ${ }^{25-27}$ The relative amount of mRNA was calculated using the comparative $\mathrm{Ct}$ method. All specific amplicons were normalized against $18 \mathrm{~S}$ rRNA, which was amplified in the same reaction as an internal control using commercial assay reagents (Applied Biosystems).

\section{Statistical Analysis}

Data are expressed as means \pm SD. Results were analyzed using parametric analysis of variance with post hoc analysis, using Bonferroni's post-test for multiple comparisons or with an unpaired $t$-test with Welch's correction. Analyses were performed with GraphPad Prism version 6.0 (GraphPad Software, San Diego, CA).

\section{Results}

\section{Syk Expression in Renal I/R Injury}

Immunostaining showed only a small number of $\mathrm{Syk}^{+}$cells in the sham-operated kidney which appeared to be mainly leukocytes (Figure 1A). In contrast, prominent Syk staining was evident in the kidney at 24 hours in vehicle-treated mice. These $\mathrm{Syk}^{+}$cells were predominantly localized to the outer medulla, and Syk staining was restricted to the interstitial space (Figure 1A). Two-color immunostaining showed that Syk was expressed by infiltrating neutrophils, macrophages, and $\mathrm{CD}_{4} 1^{+}$activated platelets in vehicletreated I/R kidney (Figure 1, B-D).

\section{CC0417 Treatment Suppresses Renal I/R Injury}

Vehicle-treated animals developed severe tubular necrosis in the outer medulla at 24 hours after I/R injury (Figure 2,
A

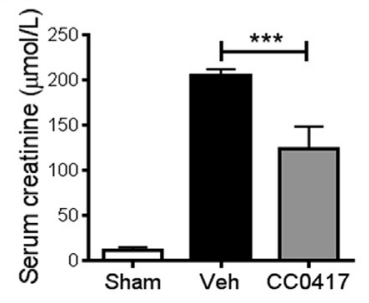

C

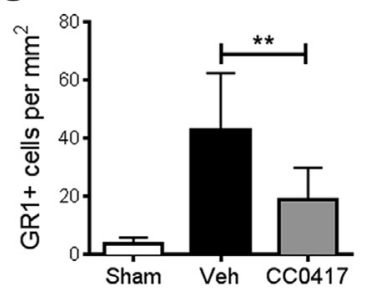

$\mathbf{E}$

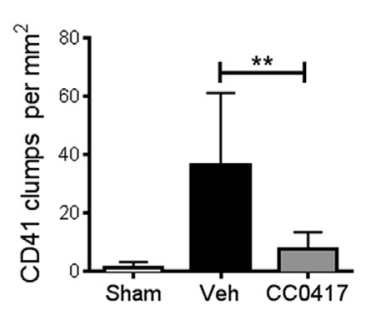

B

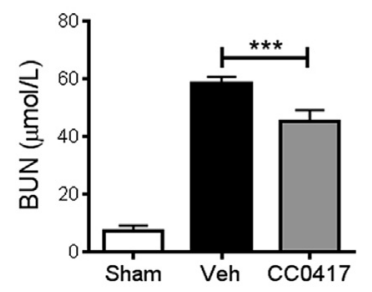

D

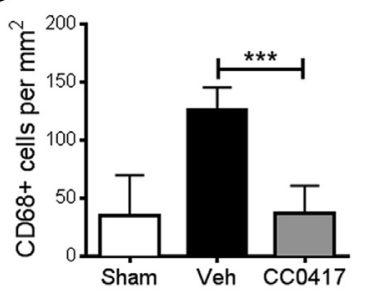

E

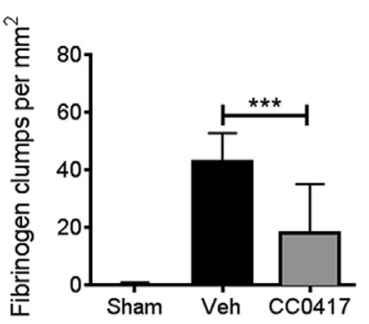

Figure 3 Effect of CCO417 on renal function, leukocyte infiltration, and platelet activation at 24 hours after renal I/R injury. A and B: Renal function as measured by serum creatinine (A) and BUN (B). C-F: Graphs showing quantification of immunostaining of tissue sections for $\mathrm{Gr}-1^{+}$neutrophils

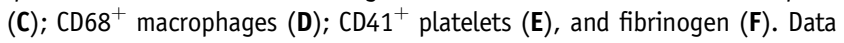
are expressed as means \pm SD. $n=8(\mathbf{A}-\mathbf{F}) .{ }^{* *} P<0.01,{ }^{* *} P<0.001$ (one-way analysis of variance with Bonferroni's multiple-comparison test). BUN, blood urea nitrogen; I/R, ischemia/reperfusion; Veh, vehicle. 
A-D). These histologic changes were evident in approximately $60 \%$ of tubules (Figure $2 \mathrm{G}$ ) and were associated with a massive up-regulation of kidney injury molecule 1 (KIM1) mRNA (Figure 2H). Consistent with the histologic examination, vehicle-treated mice developed severe renal impairment with a 17 -fold increased serum creatinine concentration and an eightfold increased blood urea nitrogen concentration (Figure 3, A and B). In contrast, treatment with CC0417 substantially reduced the severity of tubular necrosis as shown by histology and KIM-1 mRNA levels (Figure 2, E-H). This protective effect was associated with a significant improvement in renal function (Figure 3, A and B).

\section{CC0417 Treatment Reduces Leukocyte Recruitment and Platelet Activation in Renal I/R Injury}

Vehicle-treated mice featured prominent infiltration of neutrophils and macrophages, as well as platelet activation and fibrin deposition, at 24 hours of I/R injury (Figure 3, $\mathrm{C}-\mathrm{F})$. In contrast, $\mathrm{CC} 0417$ treatment markedly suppressed the accumulation of $\mathrm{Syk}^{+}$cells at 24 hours after I/R injury (Figure 1A and Figure 3, C-F). This was mirrored by a substantial reduction in neutrophil and macrophage infiltration, as well as platelet aggregation and fibrin deposition, at 24 hours in renal I/R injury (Figure 3, C-F).

To determine whether CC0417 treatment prevented the early leukocyte infiltrate and platelet activation, groups of mice were sacrificed after 30 minutes of reperfusion. A significant increase in neutrophils, macrophages, and prominent platelet deposition was evident in vehicle-treated mice at 30 minutes after I/R injury. CC0417 treatment largely abrogated neutrophil infiltration and platelet accumulation at 30 minutes after I/R injury, but it did not affect the minor macrophage infiltration (Figure 4).

\section{CC0417 Treatment Ameliorates Inflammation in Renal I/R Injury}

Analysis of leukocyte and inflammation markers was performed by real-time PCR in whole kidney tissue at 24 hours after I/R injury. CC0417 treatment significantly reduced CD68 mRNA levels (Figure 5A), consistent with immunohistochemistry data for $\mathrm{CD}^{+} 8^{+}$macrophages. This reduction in macrophage infiltration was associated with a reduction in the monocyte chemokine monocyte chemoattractant protein 1 (Figure 5B).

Markers of proinflammatory M1-type macrophages (nitric oxide synthase 2 and metalloproteinase 9 and 12) and M2-type alternatively activated macrophages (arginase-1, CD163, and CD206) were increased in vehicle-treated renal I/R injury (Figure 5, C-H). Activation of the inflammatory response in vehicle-treated I/R injury was also evident with up-regulation of mRNA levels of tumor necrosis factor- $\alpha$, IL-6, IL-1 $\beta$, IL-18, and NLR family, pyrin domain containing 3 (NLRP3) (Figure 5, I-M). CC0417 treatment significantly reduced mRNA levels of markers of both M1 and M2 type macrophages (Figure 5, C-H) and reduced
A
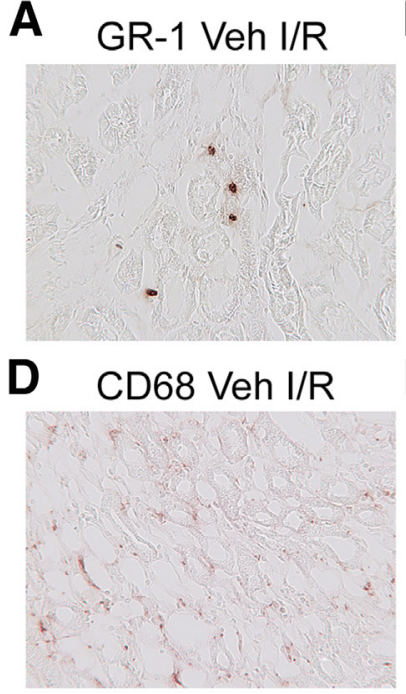

G CD41 Veh I/R

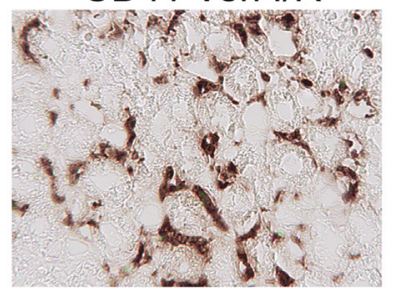

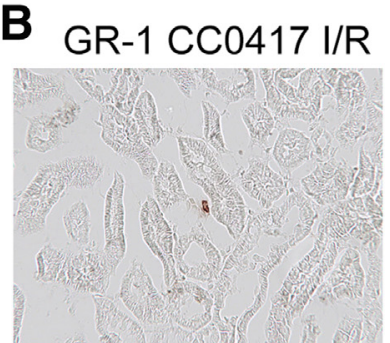
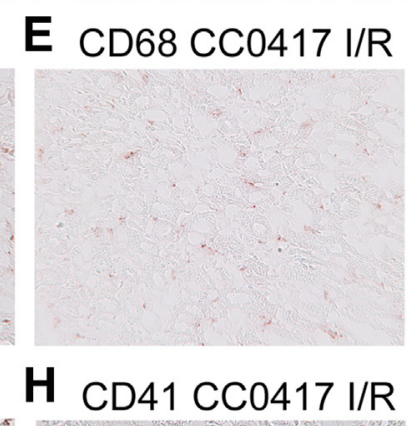
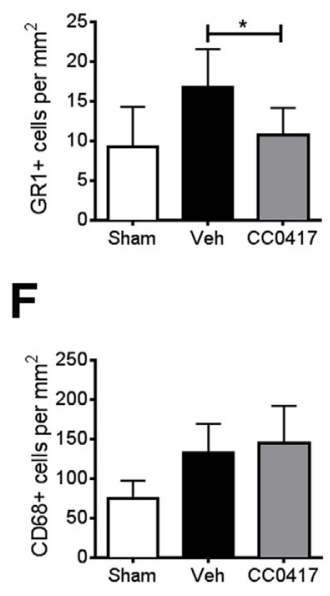

I

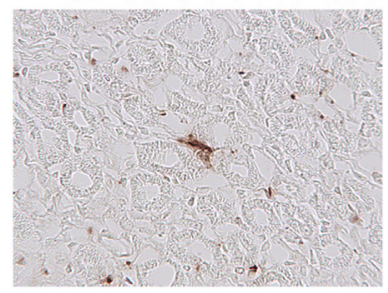

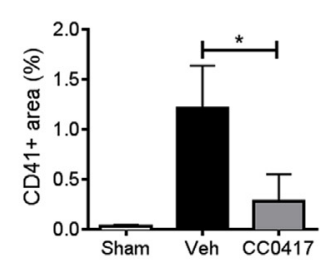

Figure 4 Effect of CCO417 on leukocyte infiltration and platelet activation at 30 minutes after renal I/R injury. A and B: Immunostaining for $\mathrm{Gr}-1^{+}$neutrophils in vehicle-treated $(\mathbf{A})$ and CC0417-treated (B) renal I/R injury. Quantification of $\mathrm{Gr}^{-} 1^{+}$neutrophils. C-E: Immunostaining for $\mathrm{CD} 8^{+}$macrophages (C) in vehicle-treated (D) and CC0417-treated (E) renal I/R injury. F: Quantification of $\mathrm{CD} 68^{+}$macrophages. $\mathbf{G}$ and $\mathbf{H}$ : Immunostaining for $\mathrm{CD}_{4} 1^{+}$platelets in vehicle-treated (G) and CC0417-treated (H) renal I/R injury. I: Quantification of $\mathrm{CD} 41^{+}$platelets. Data are expressed as means $\pm \mathrm{SD} . n=8$. ${ }^{*} P<0.05$ (oneway analysis of variance with Bonferroni's multiple-comparison test). Original magnification: $\times 400($ A , B, G, and H); $\times 250$ (D and E). I/R, ischemia/reperfusion; Veh, vehicle. 
A

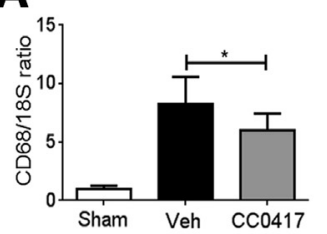

F
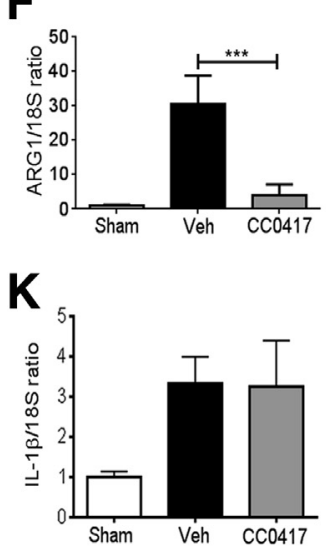

B

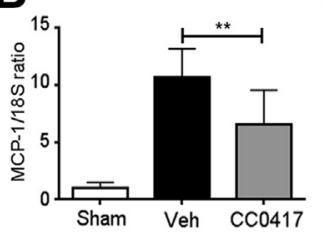

G
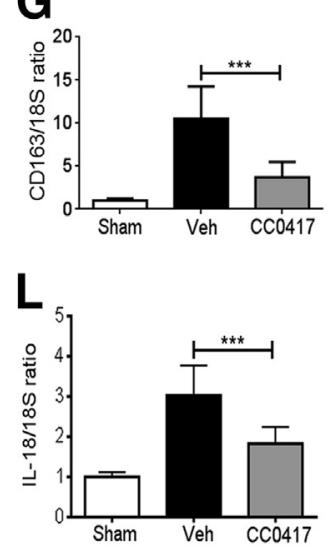
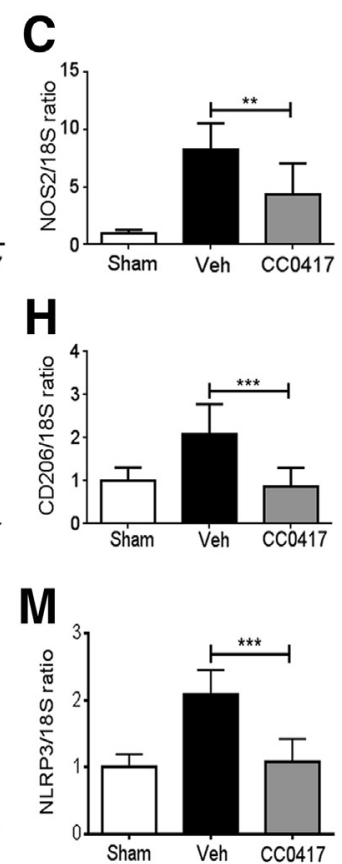

D

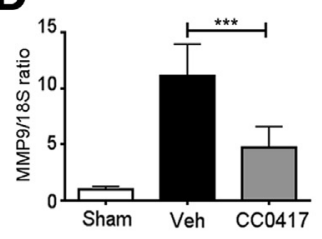

E
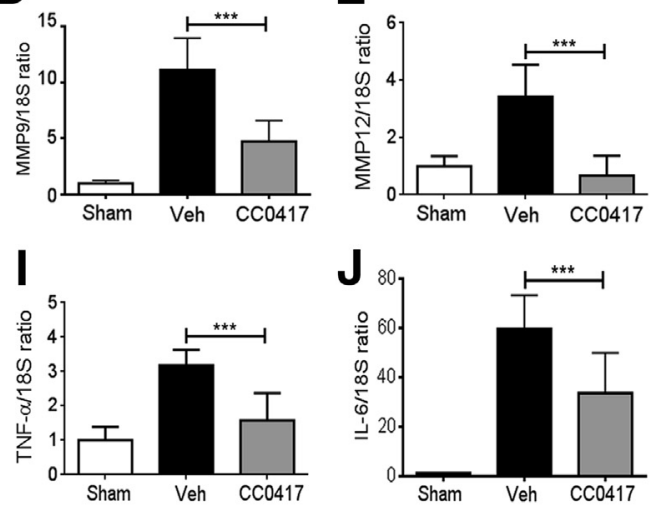

N

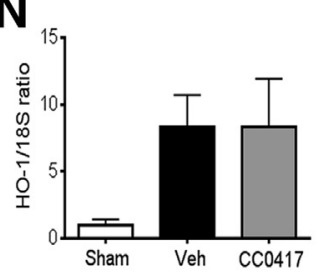

Figure 5 Effect of CCO417 on renal inflammation at 24 hours after renal I/R injury. Real-time RT-PCR analysis of whole-kidney tissue for mRNA levels of CD68 (A), MCP-1 (B), N0S2 (C), MMP-12 (D), MMP-9 (E), (ARG1) (F), CD163 (G), CD206 (H), TNF- $\alpha$ (I), IL-6 (J), IL-1 $\beta$ (K), IL-18 (L), NLRP3 (M), and H0-1 (N). Data are expressed as means \pm SD. $n=8(\mathbf{A}-\mathbf{N})$. ${ }^{*} P<0.05,{ }^{*} P<0.01$, and ${ }^{*} * P<0.001$ (one-way analysis of variance with Bonferroni's multiplecomparison test). ARG1, arginase-1; H0-1, heme oxygenase-1; I/R, ischemia/reperfusion; MCP-1, monocyte chemoattractant protein 1; MMP, metalloproteinase; NLRP3, NLR family, pyrin domain containing 3; NOS2, nitric oxide synthase 2; TNF, tumor necrosis factor; Veh, vehicle.

expression of the inflammatory response, except for IL-1 $\beta$ (Figure 5, I-M). However, CC0417 treatment had no effect on the up-regulation of heme oxygenase 1 (Figure $5 \mathrm{~N}$ ), which plays a protective role in I/R injury. ${ }^{28}$

\section{Syk Gene Deletion in Myeloid Cells Ameliorates Renal I/R Injury}

To confirm the selectivity of the kinase inhibitor study and to define the specific contribution of Syk signaling in myeloid cells, we used mice with conditional $S y k$ gene deletion. Syk ${ }^{f l f l} L y s M^{\text {Cre }}$ (abbreviated to $S y k^{M y}$ ) mice exhibit Syk deletion in most blood neutrophils and monocytes. ${ }^{23}$ These mice are healthy and have normal white blood cell counts and resident macrophage populations. ${ }^{23}$

Control $S y k^{f l / f l}$ mice developed severe tubular necrosis after renal I/R injury as illustrated by histologic examination and KIM-1 mRNA levels, and this was associated with severe renal failure (Figure 6, A, C-F). By contrast, $S y k^{M y}$ mice showed a substantial improvement in renal function and diminished tubular damage, including reduced KIM-1 mRNA levels, in response to I/R injury (Figure 6, B-F).

Renal I/R injury induced a prominent infiltrate of $\mathrm{Syk}^{+}$ cells in the outer medulla in control $S y k^{f / f l}$ mice (Figure 6, G-I). This was coincident with infiltration of neutrophils, macrophages, and platelet activation in $S y k^{f / f l}$ mice (Figure 7). However, this infiltration of neutrophils and macrophages was substantially reduced in $S y k^{M y}$ mice, whereas platelet activation showed a nonsignificant trend toward a reduction, and fibrin deposition was reduced in $S y k^{M y}$ mice (Figure 7).

The reduction in $\mathrm{CD} 68^{+}$macrophages seen in $S y k^{M y}$ mice after I/R injury was confirmed by PCR analysis of whole kidney CD68 mRNA levels, and this was associated with reduced monocyte chemoattractant protein 1 expression (Figure 8, A and B). PCR analysis showed significant increase in expression of markers of M1 and M2 type macrophages and activation of the inflammatory response after I/R injury in $S y k^{f l / f}$ mice (Figure 8, C-M). By contrast, the up-regulation of M1 and M2 markers and activation of the inflammatory response was significantly reduced in $S y k^{M y}$ mice, except for IL-1 $\beta$ (Figure 8, C-M). However, up-regulation of heme oxygenase 1 was not affected in $S y k^{M y}$ mice (Figure $8 \mathrm{~N}$ ).

\section{Discussion}

Our data provide clear evidence that Syk in myeloid cells is required for renal I/R injury. Myeloid-specific Syk gene deletion profoundly suppressed neutrophil and macrophage recruitment into the kidney and consequent renal injury. This finding was recapitulated by systemic treatment with the Syk inhibitor CC0417.

Syk is expressed by most leukocytes, except mature $\mathrm{T}$ cells, and by platelets. ${ }^{8,9}$ Two-color staining identified neutrophils, macrophages, and platelets as the major populations of Syk-expressing cells in the kidney after I/R injury. Syk expression by various nonleukocyte cell types 

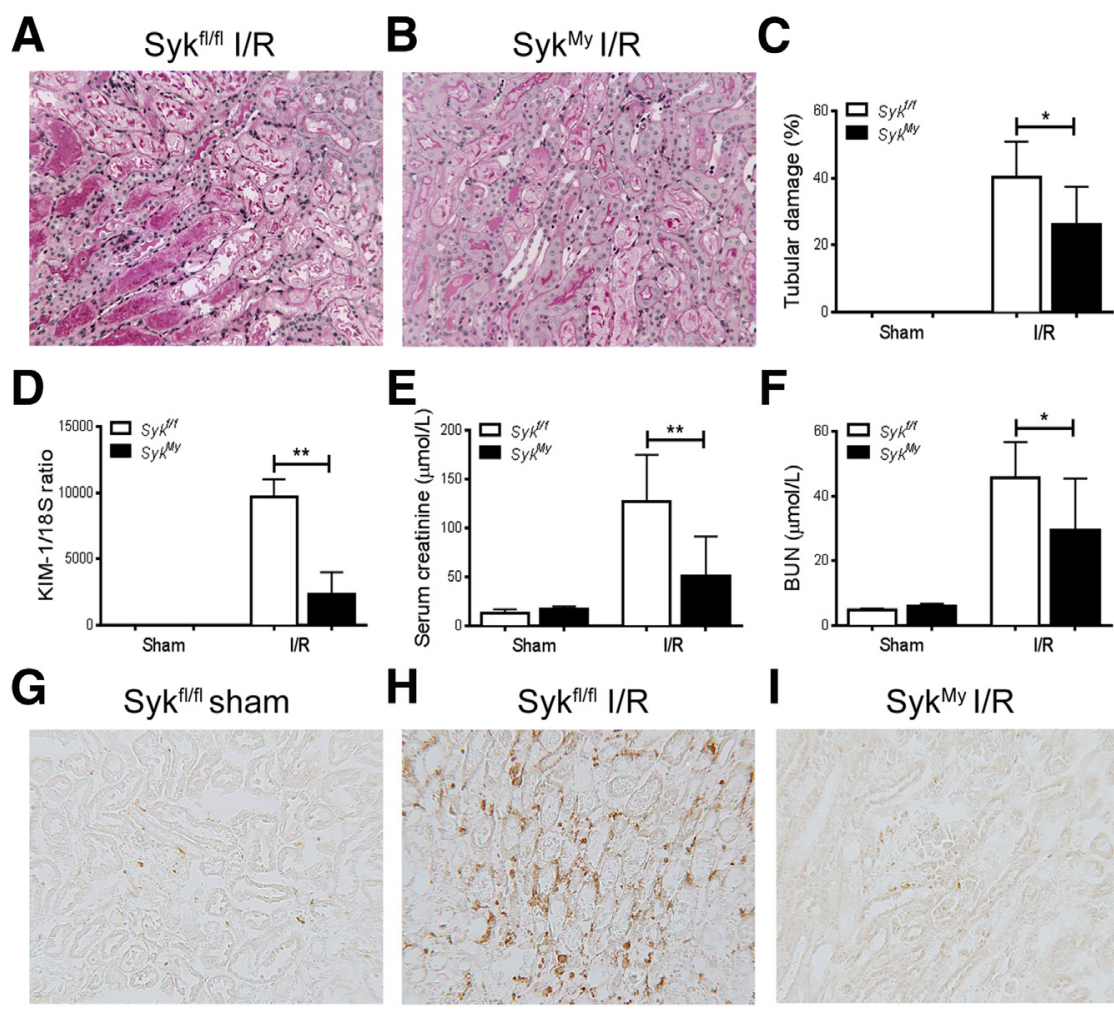

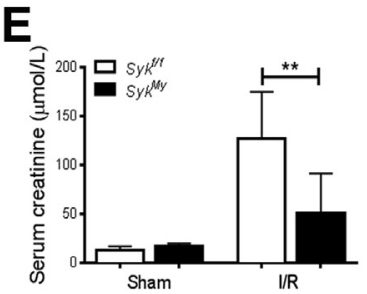

H
$\mathbf{F}$

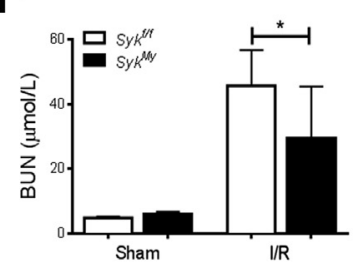

I

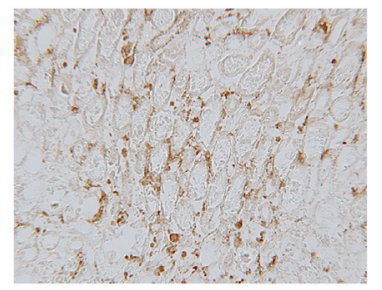

$\mathrm{Syk}^{\mathrm{My}} \mathrm{I} / \mathrm{R}$

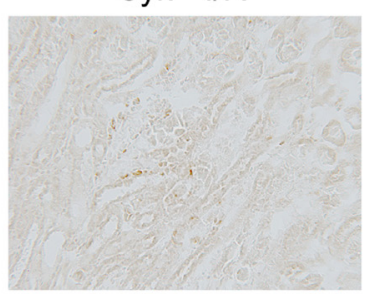

Figure 6 Effect of conditional Syk deletion in myeloid cells $\left(S y k^{M y}\right)$ compared with control Syk $k^{f l f l}$ mice on histologic damage and renal function at 24 hours after renal I/R injury. A and B: Periodic acid-Schiff-stained sections of $S_{y} k^{M y}(\mathbf{A})$ and $S y k^{f l f l}$ (B) mice after I/R injury. C: Graphs showing the percentage of injured tubules in outer medulla. D: RT-PCR analysis of KIM-1 mRNA levels in Sy ${ }^{f l f l}$ (white bar) and Syk ${ }^{M y}$ (black bar) mice. E and F: Renal function as measured by serum creatinine (E) and BUN (F). G-I: Immunoperoxidase staining for Syk in Syk $k^{f l f l}$ sham operated (G), Syk $k^{f l f l} I / R$ injury (H), and $S y k^{M y} I / R$ injury (I). Data are expressed as means \pm SD. $n=8$. ${ }^{*} P<0.05$, ${ }^{* * P}<0.01$ (one-way analysis of variance with Bonferroni's multiple-comparison test). Original magnification: $\times 250($ A, B, and G-I). BUN, blood urea nitrogen; I/R, ischemia/reperfusion; KIM-1, kidney injury molecule 1 ; SYK, spleen tyrosine kinase. has also been reported, including mesangial cells, fibroblasts, smooth muscle cells, and tubular epithelial cells, ${ }^{8,9}$ but we did not identify Syk expression in these cell types after renal I/R injury. This clear increase in Syk-expressing cells is consistent with a previous PCR-based study that identified a significant increase in Syk mRNA after renal I/R
A

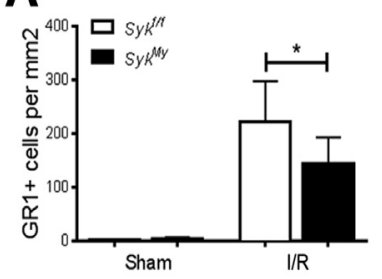

C

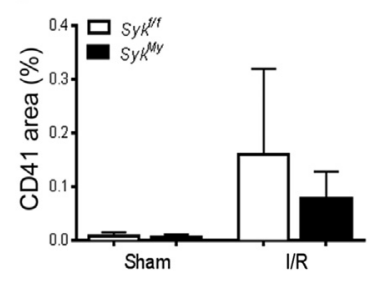

B

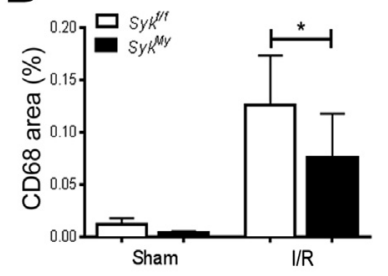

D

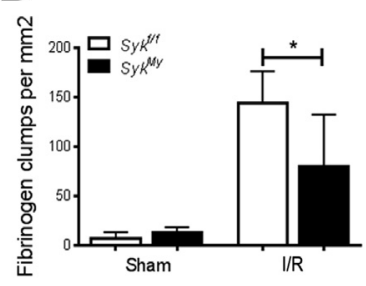

Figure 7 Effect of conditional Syk deletion in myeloid cells (Syk ${ }^{M y}$ ) compared with control Syk $k^{f l f l}$ mice on cell infiltration at 24 hours after renal I/R injury. A-D: Graphs show Gr- $1^{+}$neutrophils (A), $\mathrm{CD}^{+} 8^{+}$macrophages (B), deposition of $\mathrm{CD} 41^{+}$platelets (C), and deposition of fibrinogen (D) in Syk $k^{f l f l}$ (white bar) and Syk ${ }^{M y}$ (black bar) mice. Data are expressed as means \pm SD. $n=8$. ${ }^{*} P<0.05$ (one-way analysis of variance with Bonferroni's multiple-comparison test). I/R, ischemia/reperfusion; SKY, spleen tyrosine kinase. injury. ${ }^{7}$ However, one limitation of the present study was our inability to detect active (phosphorylation) Syk by immunohistochemistry in mouse tissue sections because of a lack of suitable commercial antibodies.

Both systemic CC0417 treatment and myeloid-specific Syk gene deletion profoundly suppressed neutrophil and macrophage recruitment into the kidney at 30 minutes and 24 hours after I/R injury. Our findings are consistent with the known role of myeloid cells in exacerbating renal I/R injury. ${ }^{6,29}$ It is well established that neutrophils attach to the disrupted endothelium and accumulate in the peritubular capillary network of the outer medulla as early as 30 minutes after reperfusion. ${ }^{29-31}$ The blockade of leukocyte endothelial adhesion molecules, including $\beta 2$-integrins, ${ }^{32}$ intercellular adhesion molecule $1,{ }^{29,33}$ E-selectin, ${ }^{34}$ and P-selectin, ${ }^{35}$ is protective in models of renal I/R injury. Importantly, Syk signaling can be activated after integrin/ligand interactions through a transmembrane adaptor, such as DNAX activation protein of $12 \mathrm{kDa}$ or the FcR common $\gamma$-chain. ${ }^{36,37}$ The mechanism underlying the blockade of myeloid cell recruitment in the present study is likely to involve Syk signaling in integrin-based myeloid cell recruitment on the basis that Syk is required for integrin-based adhesion of neutrophils to activate endothelial cells in culture ${ }^{38}$ and that chemotaxis of myeloid cells in vitro involves a Syk/integrin-dependent mechanism. ${ }^{39,40}$ However, not all neutrophil recruitment at sites of inflammation operates by a Syk-dependent mechanism, ${ }^{41}$ indicating selectivity in this process.

Platelet activation exacerbates renal I/R injury. ${ }^{42}$ A role for Syk in platelet activation by $\mathrm{Fc}$ receptor has been 

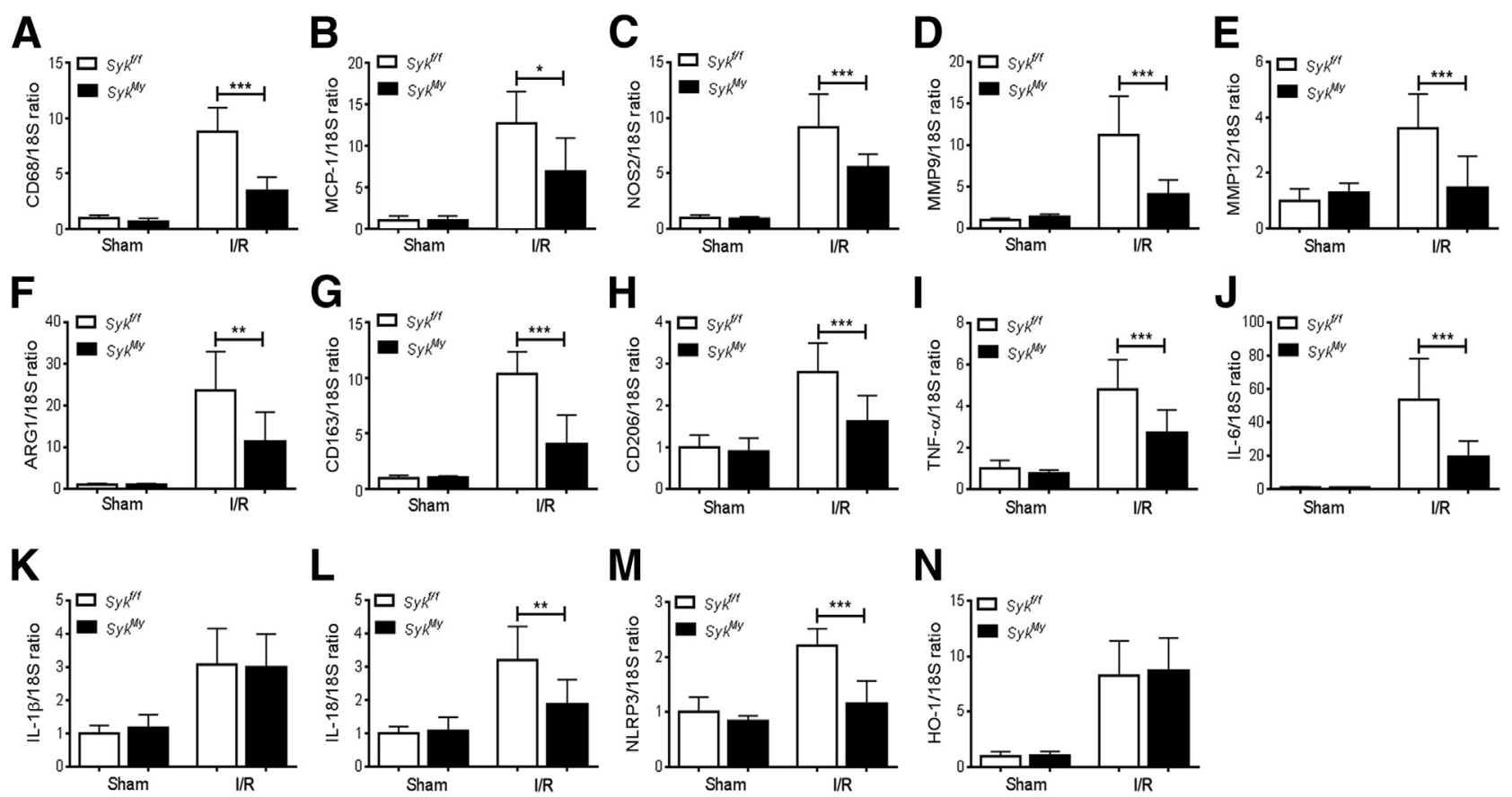

Figure 8 Effect of conditional Syk deletion in myeloid cells $\left(S y k^{M y}\right)$ compared with control Syk $k^{f l f l}$ mice on renal inflammation at 24 hours after renal I/R injury. Real-time RT-PCR analysis of whole kidney for mRNA levels of CD68 (A), MCP-1 (B), NOS2 (C), MMP-12 (D), MMP-9 (E), ARG1 (F), CD163 (G), CD206 (H), TNF- $\alpha(\mathbf{I})$, IL-6 (J), IL-1 $\beta(\mathbf{K})$, IL-18 (L), NLRP3 (M), and H0-1 (N). Data are expressed as means \pm SD. $n=8 .{ }^{*} P<0.05$, ${ }^{* *} P<0.01$, and ${ }^{* * *} P<0.001$ (oneway analysis of variance with Bonferroni's multiple-comparison test). ARG1, arginase-1; H0-1, heme oxygenase-1; I/R, ischemia/reperfusion; MCP-1, monocyte chemoattractant protein 1; MMP, metalloproteinase; NLRP3, NLR family, pyrin domain containing 3; NOS2, nitric oxide synthase 2; TNF, tumor necrosis factor; Veh, vehicle.

previously described in myocardial I/R injury. ${ }^{43,44}$ The ability of $\mathrm{CC} 0417$ to inhibit platelet activation and fibrin deposition is likely to be one of the protective actions of drug treatment and is consistent with previous studies in which a Syk inhibitor suppressed platelet activation and thrombosis in a model of acute antibody-dependent glomerular injury. ${ }^{11}$ Platelets may contribute to the accumulation of leukocytes in I/R tissue. ${ }^{45}$ However, neutrophils and macrophages also play an important role in platelet activation and thrombosis, leading to fibrin deposition. ${ }^{46,47}$ In $S y k^{M y}$ mice, the reduction in fibrin deposition and the trend toward a reduction in platelet activation in renal $I / R$ injury may be due to the reduction in myeloid cell accumulation and activation.

IL-6 is produced rapidly in response to infection and tissue injury, including in renal I/R injury. ${ }^{48}$ Both genetic and pharmacologic inhibition of IL-6 is protective in renal $\mathrm{I} / \mathrm{R}$ injury, which is associated with a substantial reduction in neutrophil infiltration and expression of tumor necrosis factor- $\alpha .{ }^{49}$ Our findings of a substantial reduction in IL-6 mRNA levels, together with a reduction in myeloid cell recruitment and tumor necrosis factor- $\alpha$ mRNA levels, are consistent with a pathologic role for IL-6 in this form of acute renal injury.

Activation of the NLRP3-associated inflammasome by the presence of necrotic cells has been implicated as a mechanism of sterile inflammation in renal I/R injury. ${ }^{50}$ Although Syk signaling is required for activation of the
Nlrp3 inflammasome in myeloid cells, this function is largely related to the process of phagocytosis, and any involvement of Syk in inflammasome activation in renal I/R injury remains to be determined. Our finding that NLRP3 and IL-18 mRNA levels were significantly reduced with genetic or pharmacologic blockade of Syk provides circumstantial evidence to support a role for Syk in inflammasome activation in renal I/R injury; however, this finding could also simply relate to the reduction in myeloid cell recruitment.

Previous studies have examined Syk in models of $I / R$ injury, using nonselective kinase inhibitors. ${ }^{17,18,20}$ Piceatannol is a naturally occurring compound found in grapes, which is often described as a selective Syk inhibitor, although it is also a potent inhibitor of $\zeta$-associated protein 70, phosphatidylinositol 3-kinase, cyclooxygenase-2, mitochondrial proton F0F1-ATPase/ATP synthase, and p56 $6^{\text {lck }} \cdot{ }^{51-54}$ Piceatannol treatment reduced the severity of tissue injury in models of retinal I/R injury ${ }^{18}$ and ischemic stroke. ${ }^{17}$ R788, also known as fostamatinib, inhibits a wide range of kinases, including Syk. ${ }^{55}$ R788 treatment inhibited both local intestinal I/R injury and remote lung injury with a significant reduction in neutrophil infiltration. ${ }^{20}$ However, it is unclear whether the beneficial effects of either of these inhibitors in I/R injury is actually due to targeting Syk. To our knowledge, our study is the first to delineate the role of Syk in $\mathrm{I} / \mathrm{R}$ injury using a conditional gene deletion approach. The excellent concordance between the results 
with myeloid cell Syk gene deletion and CC0417 treatment provides a strong argument that the beneficial effects of CC0417 are most likely due to Syk inhibition.

Syk inhibitor drugs have been used in clinical trials for multiple indications, including leukemia, ${ }^{56,57}$ arthritis, ${ }^{58,59}$ idiopathic thrombocytopenic purpura, ${ }^{60}$ and allergic rhinitis, ${ }^{61}$ demonstrating the general tolerability of these compounds. The results of the present study establish the therapeutic potential of Syk inhibitors for situations in which renal I/R injury can be anticipated. Indeed, a case for Syk inhibition as a prophylactic treatment in patients undergoing renal allograft transplantation can be made based on the following: i) results of the present study, showing benefit of Syk inhibition in anticipated renal I/R injury; ii) the recently identified role for Syk in acute antibodymediated renal allograft rejection ${ }^{21}$; and iii) the potential for Syk inhibition to suppress de novo donor-specific antibody production. ${ }^{62}$

\section{Conclusions}

We have identified a pathologic role for myeloid cell Syk signaling in renal $\mathrm{I} / \mathrm{R}$ injury using two complementary approaches. These findings identify Syk as a potential therapeutic target in acute ischemic kidney injury.

\section{Acknowledgments}

We thank Elyce Ozols for breeding and maintaining the mouse strains used in this study. Syk $k^{\text {fff }}$ mice were a gift from Professor Alexander Tarakhovsky (The Rockefeller University).

\section{References}

1. Solini S, Aiello S, Cassis P, Scudeletti P, Azzollini N, Mister M, Rocchetta F, Abbate M, Pereira RL, Noris M: Prolonged cold ischemia accelerates cellular and humoral chronic rejection in a rat model of kidney allotransplantation. Transpl Int 2012, 25:347-356

2. Basile DP, Donohoe D, Roethe K, Osborn JL: Renal ischemic injury results in permanent damage to peritubular capillaries and influences long-term function. Am J Physiol Renal Physiol 2001, 281: F887-F899

3. Menke J, Sollinger D, Schamberger B, Heemann U, Lutz J: The effect of ischemia/reperfusion on the kidney graft. Curr Opin Organ Transplant 2014, 19:395-400

4. Malek M, Nematbakhsh M: Renal ischemia/reperfusion injury; from pathophysiology to treatment. J Renal Inj Prev 2015, 4:20-27

5. Sato H, Ueki M, Asaga T, Chujo K, Maekawa N: D-ribose attenuates ischemia/reperfusion-induced renal injury by reducing neutrophil activation in rats. Tohoku J Exp Med 2009, 218:35-40

6. Huen SC, Cantley LG: Macrophage-mediated injury and repair after ischemic kidney injury. Pediatr Nephrol 2015, 30:199-209

7. Lech M, Susanti HE, Rommele C, Grobmayr R, Gunthner R, Anders HJ: Quantitative expression of C-type lectin receptors in humans and mice. Int J Mol Sci 2012, 13:10113-10131

8. Yanagi S, Inatome R, Takano T, Yamamura H: Syk expression and novel function in a wide variety of tissues. Biochem Biophys Res Commun 2001, 288:495-498
9. Mocsai A, Ruland J, Tybulewicz VL: The SYK tyrosine kinase: a crucial player in diverse biological functions. Nat Rev Immunol 2010, 10:387-402

10. Smith J, McDaid JP, Bhangal G, Chawanasuntorapoj R, Masuda ES, Cook HT, Pusey CD, Tam FW: A spleen tyrosine kinase inhibitor reduces the severity of established glomerulonephritis. J Am Soc Nephrol 2010, 21:231-236

11. Ryan J, Ma FY, Kanellis J, Delgado M, Blease K, NikolicPaterson DJ: Spleen tyrosine kinase promotes acute neutrophilmediated glomerular injury via activation of JNK and p38 MAPK in rat nephrotoxic serum nephritis. Lab Invest 2011, 91: $1727-1738$

12. Bahjat FR, Pine PR, Reitsma A, Cassafer G, Baluom M, Grillo S, Chang B, Zhao FF, Payan DG, Grossbard EB, Daikh DI: An orally bioavailable spleen tyrosine kinase inhibitor delays disease progression and prolongs survival in murine lupus. Arthritis Rheum 2008, $58: 1433-1444$

13. Deng GM, Liu L, Bahjat FR, Pine PR, Tsokos GC: Suppression of skin and kidney disease by inhibition of spleen tyrosine kinase in lupus-prone mice. Arthritis Rheum 2010, 62:2086-2092

14. Ozaki N, Suzuki S, Ishida M, Harada Y, Tanaka K, Sato Y, Kono T, Kubo M, Kitamura D, Encinas J, Hara H, Yoshida H: Syk-dependent signaling pathways in neutrophils and macrophages are indispensable in the pathogenesis of anti-collagen antibody-induced arthritis. Int Immunol 2012, 24:539-550

15. Elliott ER, Van Ziffle JA, Scapini P, Sullivan BM, Locksley RM, Lowell CA: Deletion of Syk in neutrophils prevents immune complex arthritis. J Immunol 2011, 187:4319-4330

16. Jakus Z, Simon E, Balazs B, Mocsai A: Genetic deficiency of Syk protects mice from autoantibody-induced arthritis. Arthritis Rheum 2010, 62:1899-1910

17. Suzuki $Y$, Nakano $Y$, Mishiro K, Takagi T, Tsuruma K, Nakamura M, Yoshimura S, Shimazawa M, Hara H: Involvement of Mincle and Syk in the changes to innate immunity after ischemic stroke. Sci Rep 2013, 3:3177

18. Ishizuka $F$, Shimazawa $M$, Inoue $\mathrm{Y}$, Nakano $\mathrm{Y}$, Ogishima $\mathrm{H}$, Nakamura S, Tsuruma K, Tanaka H, Inagaki N, Hara H: Toll-like receptor 4 mediates retinal ischemia/reperfusion injury through nuclear factor-kappaB and spleen tyrosine kinase activation. Invest Ophthalmol Vis Sci 2013, 54:5807-5816

19. Lapchak PH, Kannan L, Rani P, Pamuk ON, Ioannou A, Dalle Lucca JJ, Pine P, Tsokos GC: Inhibition of Syk activity by R788 in platelets prevents remote lung tissue damage after mesenteric ischemia-reperfusion injury. Am J Physiol Gastrointest Liver Physiol 2012, 302:G1416-G1422

20. Pamuk ON, Lapchak PH, Rani P, Pine P, Dalle Lucca JJ, Tsokos GC: Spleen tyrosine kinase inhibition prevents tissue damage after ischemia-reperfusion. Am J Physiol Gastrointest Liver Physiol 2010, 299:G391-G399

21. Ramessur Chandran S, Tesch GH, Han Y, Woodman N, Mulley WR, Kanellis J, Blease K, Ma FY, Nikolic-Paterson DJ: Spleen tyrosine kinase contributes to acute renal allograft rejection in the rat. Int J Exp Pathol 2015, 96:54-62

22. Saijo K, Schmedt C, Su IH, Karasuyama H, Lowell CA, Reth M, Adachi T, Patke A, Santana A, Tarakhovsky A: Essential role of Srcfamily protein tyrosine kinases in NF-kappaB activation during B cell development. Nat Immunol 2003, 4:274-279

23. Ryan J, Ma FY, Han Y, Ozols E, Kanellis J, Tesch GH, NikolicPaterson DJ: Myeloid cell-mediated renal injury in rapidly progressive glomerulonephritis depends upon spleen tyrosine kinase. J Pathol 2016, 238:10-20

24. Schneider CA, Rasband WS, Eliceiri KW: NIH Image to ImageJ: 25 years of image analysis. Nat Methods 2012, 9:671-675

25. Abraham AP, Ma FY, Mulley WR, Ozols E, Nikolic-Paterson DJ Macrophage infiltration and renal damage are independent of matrix metalloproteinase 12 in the obstructed kidney. Nephrology (Carlton) $2012,17: 322-329$ 
26. Ma FY, Tesch GH, Flavell RA, Davis RJ, Nikolic-Paterson DJ: MKK3-p38 signaling promotes apoptosis and the early inflammatory response in the obstructed mouse kidney. Am J Physiol Renal Physiol 2007, 293:F1556-F1563

27. Ma FY, Tesch GH, Ozols E, Xie M, Schneider MD, NikolicPaterson DJ: TGF-beta1-activated kinase-1 regulates inflammation and fibrosis in the obstructed kidney. Am J Physiol Renal Physiol 2011, 300:F1410-F1421

28. Ferenbach DA, Nkejabega NC, McKay J, Choudhary AK, Vernon MA, Beesley MF, Clay S, Conway BC, Marson LP, Kluth DC, Hughes J: The induction of macrophage hemeoxygenase-1 is protective during acute kidney injury in aging mice. Kidney Int 2011, 79:966-976

29. Kelly KJ, Williams WW Jr, Colvin RB, Meehan SM, Springer TA, Gutierrez-Ramos JC, Bonventre JV: Intercellular adhesion molecule1-deficient mice are protected against ischemic renal injury. J Clin Invest 1996, 97:1056-1063

30. Awad AS, Rouse M, Huang L, Vergis AL, Reutershan J, Cathro HP, Linden J, Okusa MD: Compartmentalization of neutrophils in the kidney and lung following acute ischemic kidney injury. Kidney Int 2009, 75:689-698

31. Awad AS, Ye H, Huang L, Li L, Foss FW Jr, Macdonald TL, Lynch KR, Okusa MD: Selective sphingosine 1-phosphate 1 receptor activation reduces ischemia-reperfusion injury in mouse kidney. Am J Physiol Renal Physiol 2006, 290:F1516-F1524

32. Rabb H, Mendiola CC, Dietz J, Saba SR, Issekutz TB, Abanilla F, Bonventre JV, Ramirez G: Role of CD11a and CD11b in ischemic acute renal failure in rats. Am J Physiol 1994, 267:F1052-F1058

33. Rabb H, Mendiola CC, Saba SR, Dietz JR, Smith CW, Bonventre JV, Ramirez G: Antibodies to ICAM-1 protect kidneys in severe ischemic reperfusion injury. Biochem Biophys Res Commun 1995, 211:67-73

34. Singbartl K, Ley K: Protection from ischemia-reperfusion induced severe acute renal failure by blocking E-selectin. Crit Care Med 2000, 28:2507-2514

35. Singbartl K, Green SA, Ley K: Blocking P-selectin protects from ischemia/reperfusion-induced acute renal failure. FASEB J 2000, 14: $48-54$

36. Mocsai A, Abram CL, Jakus Z, Hu Y, Lanier LL, Lowell CA: Integrin signaling in neutrophils and macrophages uses adaptors containing immunoreceptor tyrosine-based activation motifs. Nat Immunol 2006, 7:1326-1333

37. Yago T, Shao B, Miner JJ, Yao L, Klopocki AG, Maeda K, Coggeshall KM, McEver RP: E-selectin engages PSGL-1 and CD44 through a common signaling pathway to induce integrin alphaLbeta2mediated slow leukocyte rolling. Blood 2010, 116:485-494

38. Schymeinsky J, Sindrilaru A, Frommhold D, Sperandio M, Gerstl R, Then C, Mocsai A, Scharffetter-Kochanek K, Walzog B: The Vav binding site of the non-receptor tyrosine kinase Syk at Tyr 348 is critical for beta2 integrin (CD11/CD18)-mediated neutrophil migration. Blood 2006, 108:3919-3927

39. Gevrey JC, Isaac BM, Cox D: Syk is required for monocyte/macrophage chemotaxis to CX3CL1 (Fractalkine). J Immunol $2005,175: 3737-3745$

40. Schymeinsky J, Then C, Walzog B: The non-receptor tyrosine kinase Syk regulates lamellipodium formation and site-directed migration of human leukocytes. J Cell Physiol 2005, 204:614-622

41. Wex E, Bouyssou T, Duechs MJ, Erb KJ, Gantner F, Sanderson MP, Schnapp A, Stierstorfer BE, Wollin L: Induced Syk deletion leads to suppressed allergic responses but has no effect on neutrophil or monocyte migration in vivo. Eur J Immunol 2011, 41:3208-3218

42. Riera M, Torras J, Herrero I, Valles J, Paubert-Braquet M, Cruzado JM, Alsina J, Grinyo JM: Neutrophils accentuate renal cold ischemia-reperfusion injury. Dose-dependent protective effect of a platelet-activating factor receptor antagonist. J Pharmacol Exp Ther 1997, 280:786-794

43. Takaya N, Katoh Y, Iwabuchi K, Hayashi I, Konishi H, Itoh S, Okumura K, Ra C, Nagaoka I, Daida H: Platelets activated by collagen through the immunoreceptor tyrosine-based activation motif in the Fc receptor gamma-chain play a pivotal role in the development of myocardial ischemia-reperfusion injury. J Mol Cell Cardiol 2005, 39:856-864

44. Poole A, Gibbins JM, Turner M, van Vugt MJ, van de Winkel JG, Saito T, Tybulewicz VL, Watson SP: The Fc receptor gamma-chain and the tyrosine kinase Syk are essential for activation of mouse platelets by collagen. EMBO J 1997, 16:2333-2341

45. Salter JW, Krieglstein CF, Issekutz AC, Granger DN: Platelets modulate ischemia/reperfusion-induced leukocyte recruitment in the mesenteric circulation. Am J Physiol Gastrointest Liver Physiol 2001, 281:G1432-G1439

46. Ghasemzadeh M, Hosseini E: Platelet-leukocyte crosstalk: linking proinflammatory responses to procoagulant state. Thromb Res 2013, 131:191-197

47. Tipping PG, Holdsworth SR: The participation of macrophages, glomerular procoagulant activity, and factor VIII in glomerular fibrin deposition. Studies on anti-GBM antibody-induced glomerulonephritis in rabbits. Am J Pathol 1986, 124:10-17

48. Lemay S, Rabb H, Postler G, Singh AK: Prominent and sustained upregulation of gp 130-signaling cytokines and the chemokine MIP-2 in murine renal ischemia-reperfusion injury. Transplantation 2000, 69: 959-963

49. Patel NS, Chatterjee PK, Di Paola R, Mazzon E, Britti D, De Sarro A, Cuzzocrea S, Thiemermann C: Endogenous interleukin-6 enhances the renal injury, dysfunction, and inflammation caused by ischemia/reperfusion. J Pharmacol Exp Ther 2005, 312:1170-1178

50. Iyer SS, Pulskens WP, Sadler JJ, Butter LM, Teske GJ, Ulland TK, Eisenbarth SC, Florquin S, Flavell RA, Leemans JC, Sutterwala FS: Necrotic cells trigger a sterile inflammatory response through the Nlrp3 inflammasome. Proc Natl Acad Sci U S A 2009, 106: 20388-20393

51. Choi KH, Kim JE, Song NR, Son JE, Hwang MK, Byun S, Kim JH, Lee KW, Lee HJ: Phosphoinositide 3-kinase is a novel target of piceatannol for inhibiting PDGF-BB-induced proliferation and migration in human aortic smooth muscle cells. Cardiovasc Res 2010, $85: 836-844$

52. Geahlen RL, McLaughlin JL: Piceatannol (3,4,3',5'-tetrahydroxytrans-stilbene) is a naturally occurring protein-tyrosine kinase inhibitor. Biochem Biophys Res Commun 1989, 165:241-245

53. Murias M, Handler N, Erker T, Pleban K, Ecker G, Saiko P, Szekeres T, Jager W: Resveratrol analogues as selective cyclooxygenase-2 inhibitors: synthesis and structure-activity relationship. Bioorg Med Chem 2004, 12:5571-5578

54. Zheng J, Ramirez VD: Inhibition of mitochondrial proton F0F1ATPase/ATP synthase by polyphenolic phytochemicals. Br J Pharmacol 2000, 130:1115-1123

55. Rolf MG, Curwen JO, Veldman-Jones M, Eberlein C, Wang J, Harmer A, Hellawell CJ, Braddock M: In vitro pharmacological profiling of R406 identifies molecular targets underlying the clinical effects of fostamatinib. Pharmacol Res Perspect 2015, 3:e00175

56. Friedberg JW, Sharman J, Sweetenham J, Johnston PB, Vose JM, Lacasce A, Schaefer-Cutillo J, De Vos S, Sinha R, Leonard JP, Cripe LD, Gregory SA, Sterba MP, Lowe AM, Levy R, Shipp MA: Inhibition of Syk with fostamatinib disodium has significant clinical activity in non-Hodgkin lymphoma and chronic lymphocytic leukemia. Blood 2010, 115:2578-2585

57. Sharman J, Hawkins M, Kolibaba K, Boxer M, Klein L, Wu M, Hu J, Abella S, Yasenchak C: An open-label phase 2 trial of entospletinib (GS-9973), a selective spleen tyrosine kinase inhibitor, in chronic lymphocytic leukemia. Blood 2015, 125:2336-2343

58. Weinblatt ME, Kavanaugh A, Genovese MC, Jones DA, Musser TK, Grossbard EB, Magilavy DB: Effects of fostamatinib (R788), an oral spleen tyrosine kinase inhibitor, on health-related quality of life in patients with active rheumatoid arthritis: analyses of patient-reported outcomes from a randomized, double-blind, placebo-controlled trial. J Rheumatol 2013, 40:369-378 
59. Weinblatt ME, Kavanaugh A, Burgos-Vargas R, Dikranian AH, Medrano-Ramirez G, Morales-Torres JL, Murphy FT, Musser TK, Straniero N, Vicente-Gonzales AV, Grossbard E: Treatment of rheumatoid arthritis with a Syk kinase inhibitor: a twelve-week, randomized, placebo-controlled trial. Arthritis Rheum 2008, 58:3309-3318

60. Bajpai M: Fostamatinib, a Syk inhibitor prodrug for the treatment of inflammatory diseases. IDrugs 2009, 12:174-185
61. Meltzer EO, Berkowitz RB, Grossbard EB: An intranasal Syk-kinase inhibitor (R112) improves the symptoms of seasonal allergic rhinitis in a park environment. J Allergy Clin Immunol 2005, 115:791-796

62. Ackermann JA, Nys J, Schweighoffer E, McCleary S, Smithers N, Tybulewicz VL: Syk tyrosine kinase is critical for B cell antibody responses and memory B cell survival. J Immunol 2015, 194: $4650-4656$ 